\title{
Cloning of non-human primates: the road "less traveled by"
}

\author{
MICHELLE L. SPARMAN ${ }^{1}$, MASAHITO TACHIBANA ${ }^{1}$ and SHOUKHRAT M. MITALIPOV*,1,2,3 \\ ${ }^{1}$ Oregon National Primate Research Center, ${ }^{2}$ Oregon Stem Cell Center and ${ }^{3}$ Departments of Obstetrics \& \\ Gynecology and Molecular \& Medical Genetics, Oregon Health \& Science University, Beaverton, OR, USA
}

\begin{abstract}
Early studies on cloning of non-human primates by nuclear transfer utilized embryonic blastomeres from preimplantation embryos which resulted in the reproducible birth of live offspring. Soon after, the focus shifted to employing somatic cells as a source of donor nuclei (somatic cell nuclear transfer, SCNT). However, initial efforts were plagued with inefficient nuclear reprogramming and poor embryonic development when standard SCNT methods were utilized. Implementation of several key SCNT modifications was critical to overcome these problems. In particular, a non-invasive method of visualizing the metaphase chromosomes during enucleation was developed to preserve the reprogramming capacity of monkey oocytes. These modifications dramatically improved the efficiency of SCNT, yielding high blastocyst development in vitro. To date, SCNT has been successfully used to derive pluripotent embryonic stem cells (ESCs) from adult monkey skin fibroblasts. These remarkable advances have the potential for development of human autologous ESCs and cures for many human diseases. Reproductive cloning of nonhuman primates by SCNT has not been achieved yet. We have been able to establish several pregnancies with SCNT embryos which, so far, did not progress to term. In this review, we summarize the approaches, obstacles and accomplishments of SCNT in a non-human primate model.
\end{abstract}

KEY WORDS: cloning, nuclear transfer, primate, reprogramming

\section{Introduction}

Nuclear transfer (NT) efforts involving the nonhuman primate model commenced just prior to the turn of the millennium. By this time, the production of cloned offspring by nuclear transfer had been achieved in rodents, rabbits, and several species of domesticated animals using totipotent embryonic cells as the nuclear donors (McGrath and Solter, 1983; Prather et al., 1987; Sun and Moor, 1995; Willadsen, 1986). These pioneering NT efforts provoked the start of cloning in the primate model, which is the research path that our laboratory chose; the road "less traveled by". The SCNT approach would enable production of genetically identical or genetically modified animals invaluable for biomedical research and the study of human diseases. During initial attempts to study NT in the rhesus macaque (Macaca mulatta) model, individual blastomeres isolated from in vitro fertilized embryos served as nuclear donor cells (Meng et al., 1997). These blastomeres, isolated from cleavage stage embryos, were transferred into the perivitelline space of enucleated, metaphase-II stage (MII) oocytes collected following controlled ovarian stimulation (Zelinski-Wooten et al., 1995). Oocyte activation was induced immediately prior to membrane fusion by a series of electrical pulses. Resulting embryos were co-cultured on a monolayer of buffalo rat liver cells (Meng et al., 1997; Zhang et al., 1994). When 8- to 16-cell stage blastomeres were utilized as the nuclear donor cells, the results were very promising. Embryonic development to the blastocyst stage was comparable to in vitro fertilized (IVF) control embryos. Transfer of these NT embryos into surrogate animals generated four pregnancies and ultimately culminated in the live births of two healthy infants, Neti and Ditto (Meng et al., 1997). Following STR analysis, used to determine the parentage of each infant, it was definitive that both Neti and Ditto were the result of successful NT technology.

SCNT was pioneered in 1996 with the production of the first live cloned offspring (Campbell et al., 1996; Wilmut et al., 1997). This groundbreaking achievement unveiled the possibility of "resetting" the nuclei of differentiated mammalian cells back to an embryonic state, using factors present in the unfertilized oocyte to

Abbreviations used in this paper: ESC, embryonic stem cell; iPS cells, induced pluripotent stem cells; IVF, in vitro fertilized; MII, metaphase-II; MPF, maturation-promoting factor; NT, nuclear transfer; SCNT, somatic cell nuclear transfer; TSA, trichostatin A.

\footnotetext{
*Address correspondence to: Shoukhrat M. Mitalipov. 505 N.W. 185th Avenue, Beaverton, Oregon, 97006, USA. Fax: +1-503-533-2494. e-mail: mitalipo@ohsu.edu - web: http://www.ohsu.edu/xd/research/centers-institutes/onprc/scientific-discovery/scientists/mitalipov.cfm?WT_rank=1
} 
help with this reprogramming process. Studies were soon underway to examine the feasibility of cloning nonhuman primates by SCNT. It remains unknown which ooplasmic factors in the oocyte contribute to nuclear reprogramming during SCNT, but it is believed that these unidentified factors are present within the cytoplasm of MII stage oocytes. Initial SCNT studies in the monkey resulted in low blastocyst yield with a majority of embryos arresting at the cleavage stage (Mitalipov et al., 2002). Our follow up studies revealed incomplete nuclear remodeling, particularly failure to undergo nuclear envelope breakdown (NEBD) and premature chromosome condensation (PCC) following fusion of donor cells with enucleated oocytes (Mitalipov et al., 2002; Mitalipov et al., 2007). We reasoned that this phenomenon could be linked to poor subsequent development of SCNT embryos. Lack of or incomplete NEBD and PCC are generally linked to a decrease in the activity and level of maturation-promoting factor (MPF). MPF is a heterodimeric protein made up of cyclin B and cyclin-dependent kinase, which has been shown to maintain meiotic and mitotic cell phases by phosphorylating various targets within the cytoplasm, including several lamins (Peter et al., 1990; Ward and Kirschner, 1990). When an oocyte is arrested at metaphase of the second meiotic division, elevated MPF activity is detectable within the oocyte (Szollosi et al., 1988). During fertilization, the entry of sperm into the oocyte triggers intracellular calcium oscillations and ultimately results in MPF degradation (Szollosi et al., 1988). The decrease in MPF activity releases the oocyte from meiotic arrest, enabling it to complete meiosis and initiate mitotic cleavage divisions (Susko-Parrish et al., 1994). We introduced several modifications to our SCNT procedures designed to preserve MPF activity in monkey oocytes that supported improved nuclear remodeling immediately upon introduction of the donor nucleus (Mitalipov et al., 2007). Moreover, SCNT embryos produced by the modified approach progressed to the blastocyst stage at much higher rates suggesting a beneficial role of nuclear remodeling on reprogramming. To date, little is known as to what role MPF and other unidentified MII ooplasmic factors may play during nuclear reprogramming of adult somatic cells. Thus, it is critical to continue investigating various aspects of SCNT to better understand this seemingly complex cytoplasmicmediated reprogramming process. We describe here our current SCNT steps and recent efforts to produce rhesus embryonic stem cells and pregnancies from adult somatic cells.

\section{Oocyte production}

Controlled ovarian stimulation in non-human primates is routinely induced by administration of exogenous gonadotropins (Sotomaru et al., 2009; Zelinski-Wooten et al., 1995). In rhesus macaques, starting at menses (day 1-4 of their menstrual cycle), females receive twice-daily injections of recombinant human follicle stimulating hormone (FSH; Organon; $30 \mathrm{IU}$, im) for 8 days and recombinant human luteinizing hormone ( $\mathrm{LH}$; Ares Serono; $30 \mathrm{IU}, \mathrm{im}$ ) on days 7-8 of the stimulation protocol. In addition, the animals receive a gonadotropin releasing hormone $(\mathrm{GnRH})$ antagonist (Acyline; NIH/NICHD; $0.075 \mathrm{mg} / \mathrm{kg}$ body weight, sc) and human chorionic gonadotropin (hCG; Serono; 1,000 IU, im) on day 7 during the stimulation. Serum estradiol and progesterone measurements along with ultrasonographic scans are commonly performed to monitor follicular response. Oocytes are recovered via laparoscopic follicular aspiration, stripped of cumulus cells, and examined for determination of developmental stage (ZelinskiWooten et al., 1995). Only oocytes that have progressed to the MII stage of meiosis, evident by the presence of the first polar body in the perivitelline space, are used for nuclear transfer experiments.

In earlier reports, it was common to collect oocytes 27-32 hours post-hCG (Wolf et al., 1999). In our current protocols, we recover oocytes 35-36 hours post-hCG to allow oocyte maturation and spindle migration away from the polar body, thus making it easier to visualize and enucleate the meiotic spindle. In the common marmoset, ovarian stimulation commonly entails a single, daily injection of 50 IU FSH for 11 days, followed by the administration of $75 \mathrm{IU}$ hCG on the $12^{\text {th }}$ day of the stimulation protocol (Sotomaru et al., 2009). Germinal vesicle-stage oocytes, enclosed in cumulus cell-oocyte complexes, are recovered 16 hours post-hCG injection and placed in maturation medium for approximately 2224 hours (Sotomaru et al., 2009).

Oocyte availability has always been a major limitation in the nonhuman primate model. To help one understand just how limited this resource is, in 2009 we subjected 113 females to ovarian stimulations. Five of these stimulation cycles were cancelled prior to oocyte retrieval. On average, 43 oocytes were recovered per female, of which an average of 13 and 14 were mature MII and metaphase I stage, respectively. Only MII stage oocytes are suitable for SCNT, so this data indicates that less than one-third $(13 / 43,30 \%)$ of all oocytes recovered are available for SCNT. While the overall number of oocytes collected per stimulation is considerably higher compared to our results reported nearly a decade ago (Wolf et al., 1999) (43 oocytes versus 16.7 oocytes), mature oocyte availability is still limited by inefficient in vitro maturation (IVM) protocols in the nonhuman primate model, which has been thoroughly reviewed by Zheng et al. (Zheng, 2007).

\section{Oocyte enucleation}

Oocyte enucleation involves the removal of chromosomes, contained within the meiotic spindle, from unfertilized MII stage oocytes. Using the naked eye or low magnification stereomicroscopes, one cannot see these individual chromosomes or even the meiotic spindles that hold these chromosomes in place. Initial attempts to visualize this nuclear DNA utilized fluorochrome bisbenzimide (Hoechst 33342) staining and ultraviolet (UV) exposure, the standard enucleation procedure at that time (Mitalipov et al., 2002). Intact MII stage oocytes were incubated for 5 minutes with $5 \mu \mathrm{g} / \mathrm{ml}$ Hoechst 33342, placed in $30 \mu \mathrm{l}$ of Talp HEPES media (Bavister and Yanagimachi, 1977) (TH3; with 3 $\mathrm{mg} / \mathrm{ml} \mathrm{BSA}$ ) containing $5 \mu \mathrm{g} / \mathrm{ml}$ cytochalasin $\mathrm{B}$, then incubated for approximately 10-15 minutes prior to enucleation. During the enucleation procedure, the first polar body and approximately $10 \%$ of the adjacent cytoplasm is removed via aspiration directly into the enucleation pipette. Confirmation of chromosome removal was accomplished by exposing the enucleation pipette to UV wavelengths. Low blastocyst development following such approach caused us to re-evaluate each step of the SCNT protocol. While Hoechst 33342 is considered to be a live cell DNA dye, it may adversely affect oocyte and embryo viability (Velilla et al., 2002). It is likely that Hoechst 33342/UV exposure may hinder 
the developmental and reprogramming potential of the primate oocytes by inducing premature oocyte activation and MPF degradation, or by adversely reacting with mitochondrial DNA (Byrne et al., 2007; Mitalipov et al., 2007). Several non-invasive, "blind" enucleation alternatives, including 'squish' (Simerly et al., 2004) or 'one-step micromanipulation' (OSM) (Zhou et al., 2006) were also tested. The main concern with these approaches is that $100 \%$ enucleation efficiency cannot be guaranteed. We tested a new, non-invasive approach, which utilizes the latest spindle imaging technology. The Oosight spindle imaging system (CRI Oosight ${ }^{\mathrm{TM}}$ ) makes use of the birefringence properties of the microtubules, which hold the chromosomes in place within the meiotic spindle. In clinical IVF practice, previous versions of polarized microscope (Polscope) technology have been used to examine digital images of meiotic spindles (Wang et al., 2001). However, the current Oosight system allows real-time microscopy and manipulation during enucleation of meiotic chromosomes in primate oocytes (Byrne et al., 2007; Sparman et al., 2009). Plus, this allows us to consistently achieve $100 \%$ efficiency during this spindle removal procedure, without any adverse side- effects. After incorporating spindle imaging technology into our SCNT protocols, a significant increase in blastocyst formation rate (from 1\% to 16\%) was achieved (Byrne et al., 2007).

\section{Donor cell transfer and fusion}

Both the reprogramming efficiency of nuclear donor cells and subsequent embryonic development following SCNT are believed to be affected by several factors, including: the source of donor nuclei, the cell cycle stage of the recipient oocyte and the nuclear donor cell, as well as the oocyte activation method utilized. In the mouse model, the effect of different types of donor cells on SCNT cloning efficiency has been evaluated (Inoue et al., 2003). Primary cultures of fetal and adult fibroblasts are commonly used as nuclear donor cells, although other cell types including myoblasts, neurons, and Sertoli cells have also been tested (Powell et al., 2004). Numerous factors may affect the nuclear donor cell ability to support development following SCNT (e.g. isolation procedures and in vitro culture conditions, age of donor animals, etc.). In addition, it appears that lower passage cells have an advantage over higher passage cells (Powell et al., 2004). Using cynomolgus monkeys, higher blastocyst development was reported following the use of fetal fibroblasts compared to other donor cell types (OkaharaNarita et al., 2007). In the rhesus model, both fetal and adult fibroblast cell lines have been successfully implemented as nuclear donor cells for SCNT and routinely produce blastocysts (Byrne et al., 2007; Mitalipov et al., 2007; Sparman et al., 2009; Zhou et al., 2006). Direct comparison between three different primary cultures of adult, rhesus skin fibroblasts revealed a significant (three-fold) difference in subsequent embryonic development to the blastocyst stage (Sparman et al., 2009). This finding suggests that certain donor cells may possess a higher reprogramming capability and efficiency compared to other cells, although the mechanisms for this difference are not yet clear. It is thought that the differences in epigenetic characteristics amongst different nuclear donor cells may affect the cell's reprogramming and developmental potential (Humpherys et al., 2001).

During standard primate SCNT (represented in the schematic in Fig. 1), cell fusion is induced using electroporation (Byrne et al., 2007; Mitalipov et al., 2002). In brief, oocyte-donor cell complexes are exposed to two $50 \mu \mathrm{s}$ DC pulses of $2.7 \mathrm{kV} / \mathrm{cm}$ in $0.25 \mathrm{M} \mathrm{D-}$ sorbitol buffer containing $0.1 \mathrm{mM}$ calcium acetate, $0.5 \mathrm{mM}$ magnesium acetate, $0.5 \mathrm{mM} \mathrm{HEPES}$ and $1 \mathrm{mg} / \mathrm{ml}$ fatty acid-free BSA. Approximately 30 minutes following electroporation, fusion is confirmed by the absence of the donor cell in the perivitelline space of the reconstructed embryo. Based on recent results obtained in our laboratory during the spindle-chromosomal complex transfer between MII stage oocytes (Tachibana et al., 2009), we determined that exposure to the electrofusion regimen can trigger premature activation and subsequent resumption of meiosis. In order to sustain higher MPF activity before activation, we incorporated an alternative fusion technique utilizing an extract
Fig. 1. A schematic of the somatic cell nuclear transfer procedure to isolate pluripotent embryonic stem cell lines. 
from Sendai virus (SeV; http://www.cosmobio.co.jp) (Tachibana et al., 2009). During the SCNT procedure, the nuclear donor cells (e.g. fibroblasts) are immersed in the SeV extract (30-60 seconds) prior to being transferred into the perivitelline space. Cell membrane fusion between the nuclear donor cell and the oocyte typically occurs within 20-30 minutes. Fusion rates following $\mathrm{SeV}$ are similar or higher than what we previously reported following the use of electroporation (Byrne et al., 2007; Sparman et al., 2009).

\section{Oocyte activation}

Mammalian oocytes naturally go through a process called "activation" following fertilization to help the egg prepare for subsequent development. Successful oocyte activation promotes an increase in metabolic activity and releases the oocyte from meiotic arrest, thus enabling the resumption of the mitotic cell cycle (Susko-Parrish et al., 1994). During the SCNT procedure, as no sperm come into contact with the oocyte, an artificial activation method is required. Such artificial oocyte activation can be achieved by the use of chemical treatments which successfully induce calcium oscillations, much like those detected following normal fertilization with sperm. Examples of several proven methods of oocyte activation in the monkey model include treatment with ionomycin/6-dimethylaminopurine (DMAP), electroporation/cycloheximide/cytochalasin B, and ionomycin/ roscovitine/cytochalasin B (Mitalipov et al., 2001). In our lab, reconstructed oocytes are typically activated 2 hours post-fusion, to allow nuclear remodeling to occur (Byrne et al., 2007; Sparman et al., 2009). Following the standard SCNT activation protocol (Mitalipov et al., 2007), all reconstructed oocytes are exposed first to $5 \mu \mathrm{m}$ ionomycin for 5 minutes followed by a 5 hour incubation in 2 mM 6-dimethylaminopurine (DMAP). Treatment with DMAP prevents completion of meiosis and extrusion of the second polar body (Mitalipov et al., 2001). We refer to this type of activation procedure as "regular" activation. One recent change to our SCNT activation protocol has been the testing of an "instant" activation technique, in which the 2 hour incubation period after fusion (prior to the start of activation) has been completely eliminated. In such a case, fused embryos are immediately activated with DMAP and placed in culture. Our recent comparison of blastocyst development following the "regular" versus "instant" activation demonstrated the beneficial effect of the latter treatment (Table 1).

\section{Histone deacetylase inhibitor treatment}

Recent studies indicate that cloning efficiency after SCNT in the mouse, pig and bovine model could be improved with trichostatin A (TSA) treatment, a histone deacetylase inhibitor (Ding et al., 2008; Kishigami et al., 2006; Li et al., 2008). Histone deacetylation is one of the commonly studied epigenetic modifications. Inefficient nuclear reprogramming of the donor cell during SCNT may be attributed to abnormal epigenetic modification. It has been shown that treatment with TSA reduces the activity of histone deacetylase, thus resulting in an increased level of histone acetylation and enhanced regulation of DNA methylation (Yoshida et al., 1990). In theory, enhancing epigenetic regulation may positively affect the reprogramming of the somatic genome
TABLE 1

\section{DEVELOPMENT OF MONKEY SCNT EMBRYOS FOLLOWING INSTANT OR REGULAR ACTIVATION}

\begin{tabular}{lccccccc} 
Activation & $\begin{array}{c}\text { \# of } \\
\text { replicates }\end{array}$ & $\begin{array}{c}\text { \# of } \\
\text { oocytes }\end{array}$ & $\begin{array}{c}\text { Fusion } \\
(\%)\end{array}$ & $\begin{array}{c}\text { Pronuclei } \\
(\%)\end{array}$ & $\begin{array}{c}\text { 8-cell } \\
(\%)^{*}\end{array}$ & $\begin{array}{c}\text { Morulae } \\
(\%)\end{array}$ & $\begin{array}{c}\text { Blastocyst } \\
(\%)^{*}\end{array}$ \\
\hline Instant & 7 & 46 & 45 & 45 & 40 & 22 & 9 \\
Regular & 7 & 42 & $\begin{array}{c}42 \\
(100 \%)\end{array}$ & $\begin{array}{c}(100 \%) \\
(100 \%)\end{array}$ & $\begin{array}{c}(89 \%) \\
(49 \%)\end{array}$ & $\begin{array}{c}(49 \%) \\
(38 \%)\end{array}$ & $\begin{array}{c}(12 \%) \\
(12 \%)\end{array}$ \\
\hline
\end{tabular}

"Percentages are calculated based on the number of embryos forming pronuclei.

TABLE 2

\section{EFFECT OF TSA ON DEVELOPMENT OF MONKEY SCNT EMBRYOS}

\begin{tabular}{|c|c|c|c|c|c|c|c|}
\hline TSA & $\begin{array}{c}\text { \# of } \\
\text { replicates }\end{array}$ & $\begin{array}{c}\text { \# of } \\
\text { oocytes }\end{array}$ & $\begin{array}{c}\text { Fusion } \\
(\%)\end{array}$ & $\begin{array}{l}\text { Pronuclei } \\
(\%)\end{array}$ & $\begin{array}{c}\text { 8-cell } \\
(\%)^{*}\end{array}$ & $\begin{array}{c}\text { Morulae } \\
(\%)^{*}\end{array}$ & $\begin{array}{c}\text { Blastocyst } \\
(\%)^{*}\end{array}$ \\
\hline Control & 9 & 90 & $\begin{array}{c}85 \\
(94 \%)\end{array}$ & $\begin{array}{c}84 \\
(99 \%)\end{array}$ & $\begin{array}{c}81 \\
(96 \%)\end{array}$ & $\begin{array}{c}47 \\
(56 \%)\end{array}$ & $\begin{array}{c}4 \\
(5 \%)^{\mathrm{a}}\end{array}$ \\
\hline $37.5 \mathrm{nM}$ TSA & 32 & 243 & $\begin{array}{c}242 \\
(99 \%)\end{array}$ & $\begin{array}{c}242 \\
(100 \%)\end{array}$ & $\begin{array}{l}229 \\
(95)\end{array}$ & $\begin{array}{c}148 \\
(61 \%)\end{array}$ & $\begin{array}{c}43 \\
(18 \%)^{b}\end{array}$ \\
\hline
\end{tabular}

a,b Different superscripts indicate significant difference $(p<0.05)$. "Percentages are calculated based on the number of embryos forming pronuclei. Both groups were activated by the "regular" activation protocol.

TABLE 3

EMBRYO TRANSFERS WITH MONKEY SCNT EMBRYOS GENERATED FROM ADULT SOMATIC CELLS

\begin{tabular}{lccc} 
Treatment & $\begin{array}{c}\text { \# of } \\
\text { recipients }\end{array}$ & $\begin{array}{c}\text { \# of embryos } \\
\text { transferred }\end{array}$ & $\begin{array}{c}\text { \# of pregnancies } \\
\text { (\# of clinical pregnancies) }\end{array}$ \\
\hline Control & 12 & 55 & 0 \\
With TSA & 10 & 67 & $6(5)$ \\
\hline
\end{tabular}

Recovered oocytes were divided into two groups and both groups were activated by the "regular" activation protocol. "One biochemical pregnancy was confirmed by the continual rise in E2 and P4 levels.

(Li et al., 2008). We tested the effect of TSA exposure during the SCNT procedure in the primate model. Fused SCNT embryos were first incubated with $37.5 \mathrm{nM}$ TSA for 5 hours during DMAP treatment. Activated embryos were then transferred into embryo culture media containing 37.5 nM TSA for an additional 17-19 hours. In total, SCNT embryos were exposed to TSA for 22-24 hours. Based on our recent results, TSA treatment significantly improved the percentage of SCNT embryos that reached the blastocyst stage (Table 2). Moreover, the subsequent in vivo development following transfer of SCNT blastocysts into recipients was also dramatically improved in the TSA group (Table 3). While further testing could be required to optimize the proper concentration and timing of TSA supplementation, we have modified our current SCNT procedures to include the TSA.

\section{ES cell derivation and embryo transfer}

In the mid-1990's, Dr. James Thomson of the Wisconsin National Primate Research Center reported the isolation of the first embryonic stem cell (ESC) lines from rhesus macaque blastocysts (Thomson et al., 1995). These primate ESCs were maintained in an undifferentiated state while cultured on feeder 

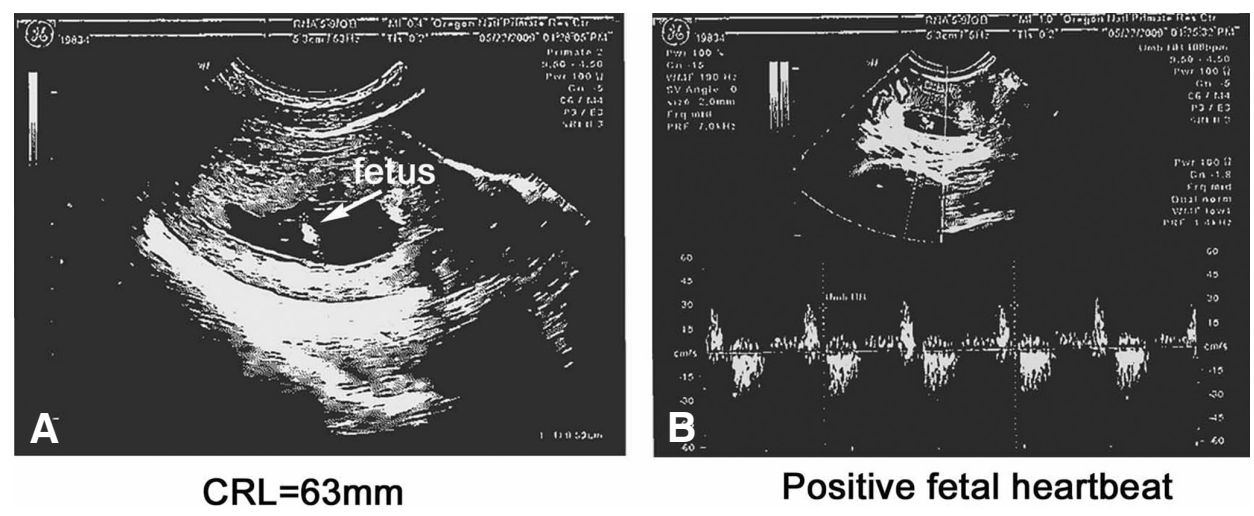

Fig. 2. Ultrasound images of the SCNT pregnancy. (A) Ultrasonography revealed a fetus with a crown-rump length (CRL) of $63 \mathrm{~mm}$ in the gestational sac. (B) A positive fetal heartbeat was detected in the SCNT fetus.

layers but retained the potential to differentiate into cells representing all three germ cell layers (endoderm, mesoderm, and ectoderm) (Thomson et al., 1995; Thomson et al., 1996). Prior to the establishment of rhesus ESCs, only mouse ESCs were available (Martin, 1981). Primate ESCs provided an exciting model for better understanding human development and disease in vitro and in vivo. As one would expect, following protocols and markers developed for monkey ESCs, studies were soon carried out with human embryos that culminated in the successful derivation of human ESCs (Thomson et al., 1998).

Coupling of ESC research with SCNT technology also catalyzed the development of new strategies for reprogramming somatic cells and deriving patient-matched pluripotent cells (Byrne et al., 2007). The ability to derive pluripotent cells that are genetically identical to individual patients, holds tremendous potential to produce cells that will not be rejected by the patient's immune system and that may help prevent numerous degenerative diseases (Drukker and Benvenisty, 2004; McKay, 2000). We employed a modified SCNT approach to produce blastocysts from adult rhesus macaque skin fibroblasts and established two ESC lines from these cloned embryos, designated as CRES-1 and CRES-2 (Byrne et al., 2007). These CRES cell lines are genetically identical to each other in terms of nuclear DNA, since nuclear donor cells employed were from the same adult male. However, these cell lines contain different mitochondrial genomes since oocytes from two different females were used for SCNT. Characterization of these novel SCNT-derived ESC lines confirmed their pluripotency and origin from somatic cells (Byrne et al., 2007).

As for the efficiency of this approach, in our initial study we used a total of 304 oocytes to derive two CRES cell lines; less than a $1 \%$ derivation efficiency rate. While the low efficiency rates still leave room for improvement, these results suggest that nuclear reprogramming by SCNT can support derivation of ESCs in higher primates, including humans. In a more recent study, we used adult rhesus female skin fibroblasts for SCNT and derived two additional ESC lines (CRES-3 and CRES-4) (Sparman et al., 2009). Further optimizations and improvements in SCNT resulted in a nearly three-fold higher blastocyst development rate (43\%) and ESC derivation rate $(29 \%)$ as compared to the previous outcomes (Byrne et al., 2007). Of particular interest, the oocytes that gave rise to CRES- 3 and -4 were all recovered from only one rhesus female, subjected to a single controlled ovarian stimulation. These findings reveal that it is now possible to derive a primate stem cell line from as few as 10 oocytes, or less, and that it may be economically and technically feasible to derive patientmatched ESCs for tissue replacement therapy.

The nonhuman primate is clearly an attractive research model for SCNT because of its remarkable similarity to humans, genetically and from a reproductive standpoint. The benefits of producing rhesus monkeys by reproductive cloning for biomedical research are tremendous. For instance, the production of genetically identical monkeys would significantly reduce the number of animals utilized in biomedical research. Another advantage is that we can carry out a variety of genetic manipulations with cultured nuclear donor cells, including gene targeting. Reproductive cloning with such cells would allow for the production of genetically modified primates, including gene knock-out models, to study gene function and human diseases.

At present, the production of live primate offspring following SCNT has yet to be accomplished (Mitalipov et al., 2002; Simerly et al., 2003). We summarize here our recent unpublished efforts in embryo transfer using rhesus blastocysts produced by SCNT with adult monkey skin cells expressing GFP (Table 3). A total of 5 pregnancies were established following transfer of 67 embryos into 10 recipients (Tables 3 and 4). Only one pregnancy resulted in a live fetus that possessed a fetal heartbeat, detected by ultrasonographic scans, while other pregnancies contained sacs without a fetus (Fig. 2). Unfortunately, this pregnancy failed to go to term and was aborted at day 81 of gestation. To determine if there was an abnormal phenotype in the aborted cloned pregnancy, we recovered fetal tissues and carried out histological and molecular analyses. The SCNT origin of the fetus was confirmed by both GFP-specific PCR and direct observation of GFP expres-

TABLE 4

\section{SCNT PREGNANCY OUTCOMES}

\begin{tabular}{|c|c|c|c|c|c|c|}
\hline Recipient & $\begin{array}{c}\text { \# of embryos } \\
\text { transferred }\end{array}$ & $\begin{array}{c}\text { Embryonic } \\
\text { age } \\
\text { (stage) }\end{array}$ & $\begin{array}{l}\text { Recipient } \\
\text { stage }\end{array}$ & \# of GS & $\begin{array}{c}\text { \# of } \\
\text { fetuses }\end{array}$ & Outcome \\
\hline 1 & 8 & $\begin{array}{c}\text { D4 } \\
(\mathrm{M} / \mathrm{CM})\end{array}$ & D2 & 1 & 0 & \\
\hline 2 & 8 & $\begin{array}{c}\text { D4 } \\
(\mathrm{M} / \mathrm{CM})\end{array}$ & D2 & 1 & 0 & \\
\hline 3 & 3 & $\begin{array}{c}\mathrm{D} 13 \\
\text { (Blastocyst) }\end{array}$ & D4 & 1 & 0 & \\
\hline 4 & 8 & $\begin{array}{c}\text { D4 } \\
\text { (16-cell/M) }\end{array}$ & D2 & 1 & 1 & $\begin{array}{c}\text { aborted at } 81 \\
\text { days of gestation }\end{array}$ \\
\hline 5 & 7 & $\begin{array}{c}\mathrm{D} 6 \\
(\mathrm{M} / \mathrm{CM})\end{array}$ & D3 & 1 & 0 & \\
\hline
\end{tabular}

"Embryonic age, measures the actual age of the embryo, in days, from the time of fertilization (e.g D4 = day 4 post-fertilization). "Stage, refers to the embryo stage of development at the time of the embryo transfer (e.g. $\mathrm{M}=$ Morula; $\mathrm{CM}=$ Compact morula). ${ }^{* * *}$ Recipient stage, measures the stage of the recipient's uterus, in days, post-ovulation $(\mathrm{D} 0=$ day of ovulation, so $\mathrm{D} 2=$ day 2 postovulation). GS, Gestational sac 
A

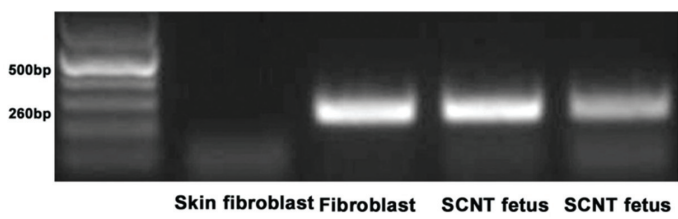

Skin fibroblast Fibroblast SCNT fetus SCNT fetus

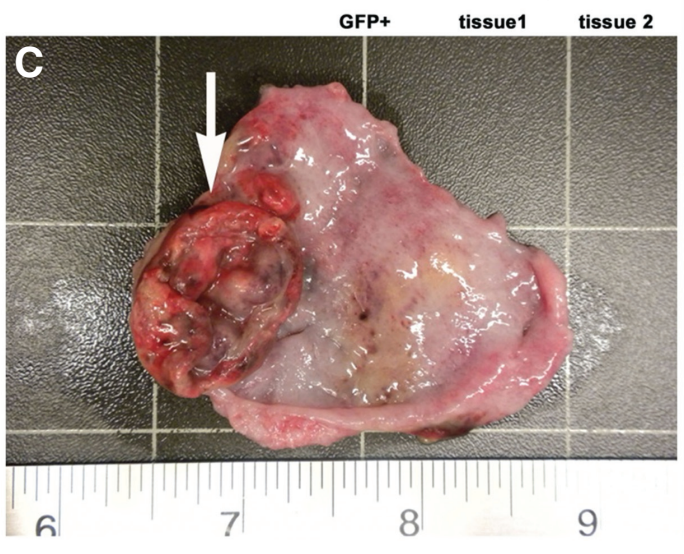

Fig. 3. Analysis of aborted SCNT fetal tissues. (A) GFP detection by PCR amplification using eGFP specific primers. (B) Direct GFP expression in fetal tissues (40x magnification). (C) Macroscopic examination of fetal components of the aborted SCNT pregnancy (indicated by an arrow). (D) Histological examination of frozen section by HS staining (40x magnification) detecting endodermal and mesodermal components within the recovered tissue.
B

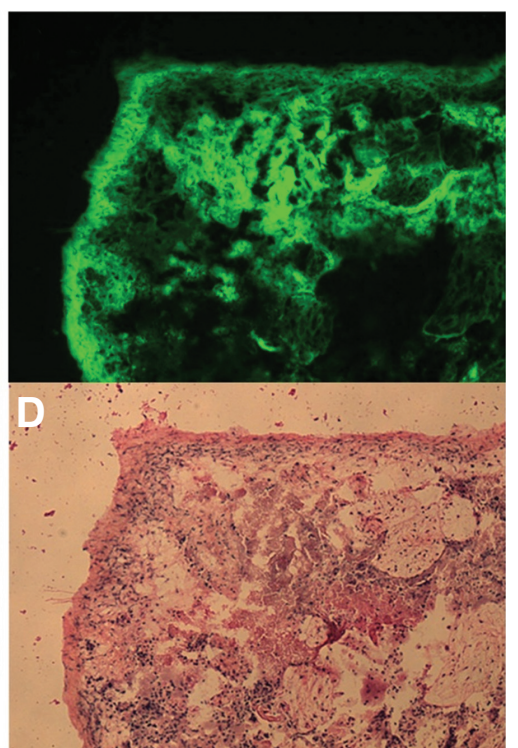

cells, genetically identical to the patient, can now be derived by the reprogramming of somatic cells using SCNT or induced pluripotent stem (iPS) cell approaches (Yu et al., 2007). Recently, iPS cells were also generated from somatic cells in several nonhuman primate species, including cynomolgus monkeys (Jin et al., 2009), marmosets (Wu et al.), and rhesus macaques (Liu et al., 2008). The ability to generate pluripotent stem cells without using oocytes is a major advance in the field. However, recent mouse studies indicate that SCNT derived ESCs are superior to their iPS counterparts in terms of differentiation capacity in vitro and in vivo (Kim et al., 2010; Polo et al., 2010).

Therefore, comparative studies of SCNT and iPS derived stem cells must be carried out in order to further elucidate advantages and disadvantages of these two types of experimentally generated pluripotent cells.

Although no live primate infants have been produced by SCNT at this time, clinical pregnancies have been established following embryo transfer attempts using SCNT embryos in several nonhuman prision (Fig. 3 A,B). Macroscopically, results demonstrated poor placental development with fewer chorionic villi compared to controls (Fig. 3C). Microscopically, the fetal tissue also lacked ectodermal components (Fig. 3D). These observations suggest possible insufficient development of the placental component that ultimately impaired the development of the resulting fetus.

\section{Conclusions and future directions}

Looking back at the progress made in primate SCNT in just over a decade, it is quite remarkable to see how quickly this technology has advanced, especially considering that just a few research groups are working in this area with nonhuman primates. Within only two years from the start of NT in primates, two rhesus macaque infants were already produced using embryonic cells as the nuclear donor cells. In order to demonstrate that successful nuclear transfer could be accomplished in primates using somatic cells, SCNT protocols, initially developed in other species, were tested with limited success. Introduction of a few key modifications to SCNT technology resulted in enhanced embryonic development and blastocyst yield in both cynomolgus ( $\mathrm{Ng}$ et al., 2004) and rhesus macaques (Byrne et al., 2007; Sparman et al., 2009).

As the first proof-of principle in primates, functional embryonic stem cell lines were established from rhesus SCNT embryos using adult skin fibroblasts (Byrne et al., 2007; Sparman et al., 2009). The ability to derive ESCs by SCNT holds great potential for regenerative medicine (McKay, 2000). Allogenic ESCs derived from in vitro fertilized (IVF) embryos would be rejected by the patient's immune system, unless the patient was treated with ongoing immunosuppressive medication (Drukker and Benvenisty, 2004). Isogenic pluripotent stem

mate species. While therapeutic cloning has yet to be achieved in humans, our recent improvements in the protocols in the nonhuman primate model give hope for success in the future (Byrne et al., 2007; Sparman et al., 2009).

In conclusion, we provide here an overview of the current state of SCNT research in the rhesus macaque model. Remarkable progress has been made in adapting and optimizing SCNT protocols to produce embryos and ESCs from adult monkey somatic cells. In contrast, the in vivo development of monkey SCNT embryos following transfer into recipients is still limited, thus necessitating further studies to help us better understand the mechanisms of reprogramming in primates. With this, we would like to conclude with a few lines from the famous The Road Not Taken poem by Robert Frost:

Two roads diverged in a wood,

and I -

I took the one less traveled by, and that has made all the difference.

\section{Acknowledgements}

The authors would like to recognize the expertise and services provided by the Division of Animal Resources, Assisted Reproductive Technology \& ESC Core, Surgical Team, Endocrine Services Core, Imaging \& Morphology Core, and Molecular \& Cellular Biology Core at the Oregon National Primate Research Center (ONPRC). We are also grateful to Tomita Tatsuo for assisting with the microscopic analysis of the recovered SCNT fetal tissue, as well as Organon International and Ares Advanced Technology, Inc. (Ares Serono) for their generous donation of the recombinant human gonadotropins used in this study. This work was largely supported by funds from ONPRC, Oregon Stem Cell Center and by grants from the National Institutes of Health HD057121, HD059946, HD063276, RR000163, HD047675, HD018185, and HD047721. 


\section{References}

BAVISTER, B.D. and YANAGIMACHI (1977). The effects of sperm extracts and energy sources on the motility and acrosome reaction of hamster spermatozoa in vitro. Biol Reprod 16: 228-237.

BYRNE, J.A., PEDERSEN, D.A., CLEPPER, L.L., NELSON, M., SANGER, W.G., GOKHALE, S., WOLF, D.P. and MITALIPOV, S.M. (2007). Producing primate embryonic stem cells by somatic cell nuclear transfer. Nature 450: 497-502.

CAMPBELL, K.H., MCWHIR, J., RITCHIE, W.A. and WILMUT, I. (1996). Sheep cloned by nuclear transfer from a cultured cell line. Nature 380: 64-66.

DING, X., WANG, Y., ZHANG, D., WANG, Y., GUO, Z. and ZHANG, Y. (2008). Increased pre-implantation development of cloned bovine embryos treated with 5-aza-2'-deoxycytidine and trichostatin A. Theriogenology 70: 622-630.

DRUKKER, M. and BENVENISTY, N. (2004). The immunogenicity of human embryonic stem-derived cells. Trends Biotechnol 22: 136-141.

HUMPHERYS, D., EGGAN, K., AKUTSU, H., HOCHEDLINGER, K., RIDEOUT, W.M., 3RD, BINISZKIEWICZ, D., YANAGIMACHI, R. and JAENISCH, R. (2001). Epigenetic instability in ES cells and cloned mice. Science 293: 95-97.

INOUE, K., OGONUKI, N., MOCHIDA, K., YAMAMOTO, Y., TAKANO, K., KOHDA, T., ISHINO, F. and OGURA, A. (2003). Effects of donor cell type and genotype on the efficiency of mouse somatic cell cloning. Biol Reprod 69: 1394-1400.

JIN, Z.B., OKAMOTO, S., MANDAI, M. and TAKAHASHI, M. (2009). Induced pluripotent stem cells for retinal degenerative diseases: a new perspective on the challenges. J Genet 88: 417-424.

KIM, K., DOI, A., WEN, B., NG, K., ZHAO, R., CAHAN, P., KIM, J., ARYEE, M.J., JI, H., EHRLICH, L.I. et al. (2010). Epigenetic memory in induced pluripotent stem cells. Nature 467: 285-290 (doi: 10.1038/nature09342)

KISHIGAMI, S., MIZUTANI, E., OHTA, H., HIKICHI, T., THUAN, N.V., WAKAYAMA, S., BUI, H.T. and WAKAYAMA, T. (2006). Significant improvement of mouse cloning technique by treatment with trichostatin A after somatic nuclear transfer. Biochem Biophys Res Commun 340: 183-189.

LI, J., SVARCOVA, O., VILLEMOES, K., KRAGH, P.M., SCHMIDT, M., BOGH, I.B., ZHANG, Y., DU, Y., LIN, L., PURUP, S. et al. (2008). High in vitro development after somatic cell nuclear transfer and trichostatin $A$ treatment of reconstructed porcine embryos. Theriogenology 70: 800-808.

LIU, H., ZHU, F., YONG, J., ZHANG, P., HOU, P., LI, H., JIANG, W., CAI, J., LIU, M., CUI, K. et al. (2008). Generation of induced pluripotent stem cells from adult rhesus monkey fibroblasts. Cell Stem Cell 3: 587-590.

MARTIN, G.R. (1981). Isolation of a pluripotent cell line from early mouse embryos cultured in medium conditioned by teratocarcinoma stem cells. Proc Natl Acad Sci USA 78: 7634-7638.

MCGRATH, J. and SOLTER, D. (1983). Nuclear transplantation in the mouse embryo by microsurgery and cell fusion. Science 220: 1300-1302.

MCKAY, R. (2000). Stem cells-hype and hope. Nature 406: 361-364.

MENG, L., ELY, J.J., STOUFFER, R.L. and WOLF, D.P. (1997). Rhesus monkeys produced by nuclear transfer. Biol Reprod 57: 454-459.

MITALIPOV, S.M., NUSSER, K.D. and WOLF, D.P. (2001). Parthenogenetic activation of rhesus monkey oocytes and reconstructed embryos. Biol Reprod 65: 253-259.

MITALIPOV, S.M., YEOMAN, R.R., NUSSER, K.D. and WOLF, D.P. (2002) Rhesus monkey embryos produced by nuclear transfer from embryonic blastomeres or somatic cells. Biol Reprod 66: 1367-1373.

MITALIPOV, S.M., ZHOU, Q., BYRNE, J.A., JI, W.Z., NORGREN, R.B. and WOLF, D.P. (2007). Reprogramming following somatic cell nuclear transfer in primates is dependent upon nuclear remodeling. Hum Reprod 22: 2232-2242.

NG, S.C., CHEN, N., YIP, W.Y., LIOW, S.L., TONG, G.Q., MARTELLI, B., TAN, L.G. and MARTELLI, P. (2004). The first cell cycle after transfer of somatic cell nuclei in a non-human primate. Development 131: 2475-2484.

OKAHARA-NARITA, J., TSUCHIYA, H., TAKADA, T. and TORII, R. (2007). Cloned blastocysts produced by nuclear transfer from somatic cells in cynomolgus monkeys (Macaca fascicularis). Primates 48: 232-240.

PETER, M., NAKAGAWA, J., DOREE, M., LABBE, J.C. and NIGG, E.A. (1990). In vitro disassembly of the nuclear lamina and $M$ phase-specific phosphorylation of lamins by cdc2 kinase. Cell 61: 591-602.

POLO, J.M., LIU, S., FIGUEROA, M.E., KULALERT, W., EMINLI, S., TAN, K.Y.,
APOSTOLOU, E., STADTFELD, M., LI, Y., SHIODA, T. et al. (2010). Cell type of origin influences the molecular and functional properties of mouse induced pluripotent stem cells. Nat Biotechnol 28: 848-855.

POWELL, A.M., TALBOT, N.C., WELLS, K.D., KERR, D.E., PURSEL, V.G. and WALL, R.J. (2004). Cell donor influences success of producing cattle by somatic cell nuclear transfer. Biol Reprod 71: 210-216.

PRATHER, R.S., BARNES, F.L., SIMS, M.M., ROBL, J.M., EYESTONE, W.H. and FIRST, N.L. (1987). Nuclear transplantation in the bovine embryo: assessment of donor nuclei and recipient oocyte. Biol Reprod 37: 859-866.

SIMERLY, C., DOMINKO, T., NAVARA, C., PAYNE, C., CAPUANO, S., GOSMAN, G., CHONG, K.Y., TAKAHASHI, D., CHACE, C., COMPTON, D. et al. (2003) Molecular correlates of primate nuclear transfer failures. Science 300: 297.

SIMERLY, C., NAVARA, C., HYUN, S.H., LEE, B.C., KANG, S.K., CAPUANO, S., GOSMAN, G., DOMINKO, T., CHONG, K.Y., COMPTON, D. et al. (2004). Embryogenesis and blastocyst development after somatic cell nuclear transfer in nonhuman primates: overcoming defects caused by meiotic spindle extraction. Dev Biol 276: 237-252.

SOTOMARU, Y., HIRAKAWA, R., SHIMADA, A., SHIOZAWA, S., SUGAWARA, A. OIWA, R., NOBUKIYO, A., OKANO, H., TAMAOKI, N., NOMURA, T. et al. (2009). Preimplantation development of somatic cell cloned embryos in the common marmoset (Callithrix jacchus). Cloning Stem Cells 11: 575-583.

SPARMAN, M., DIGHE, V., SRITANAUDOMCHAI, H., MA, H., RAMSEY, C., PEDERSEN, D., CLEPPER, L., NIGHOT, P., WOLF, D., HENNEBOLD, J. et al. (2009). Epigenetic reprogramming by somatic cell nuclear transfer in primates. Stem Cells 27: 1255-1264.

SUN, F.Z. and MOOR, R.M. (1995). Nuclear transplantation in mammalian eggs and embryos. Curr Top Dev Biol 30: 147-176.

SUSKO-PARRISH, J.L., LEIBFRIED-RUTLEDGE, M.L., NORTHEY, D.L., SCHUTZKUS, V. and FIRST, N.L. (1994). Inhibition of protein kinases after an induced calcium transient causes transition of bovine oocytes to embryonic cycles without meiotic completion. Dev Biol 166: 729-739.

SZOLLOSI, D., CZOLOWSKA, R., SZOLLOSI, M.S. and TARKOWSKI, A.K (1988). Remodeling of mouse thymocyte nuclei depends on the time of their transfer into activated, homologous oocytes. J Cell Sci 91 (Pt 4): 603-613.

TACHIBANA, M., SPARMAN, M., SRITANAUDOMCHAI, H., MA, H., CLEPPER, L., WOODWARD, J., LI, Y., RAMSEY, C., KOLOTUSHKINA, O. and MITALIPOV, $S$. (2009). Mitochondrial gene replacement in primate offspring and embryonic stem cells. Nature 461: 367-372.

THOMSON, J.A., ITSKOVITZ-ELDOR, J., SHAPIRO, S.S., WAKNITZ, M.A. SWIERGIEL, J.J., MARSHALL, V.S. and JONES, J.M. (1998). Embryonic stem cell lines derived from human blastocysts. Science 282: 1145-1147.

THOMSON, J.A., KALISHMAN, J., GOLOS, T.G., DURNING, M., HARRIS, C.P., BECKER, R.A. and HEARN, J.P. (1995). Isolation of a primate embryonic stem cell line. Proc Natl Acad Sci USA 92: 7844-7848.

THOMSON, J.A., KALISHMAN, J., GOLOS, T.G., DURNING, M., HARRIS, C.P. and HEARN, J.P. (1996). Pluripotent cell lines derived from common marmoset (Callithrix jacchus) blastocysts. Biol Reprod 55: 254-259.

VELILLA, E., LOPEZ-BEJAR, M., RODRIGUEZ-GONZALEZ, E., VIDAL, F. and PARAMIO, M.T. (2002). Effect of Hoechst 33342 staining on developmental competence of prepubertal goat oocytes. Zygote 10: 201-208.

WANG, W.H., MENG, L., HACKETT, R.J. and KEEFE, D.L. (2001). Developmental ability of human oocytes with or without birefringent spindles imaged by Polscope before insemination. Hum Reprod 16: 1464-1468.

WARD, G.E. and KIRSCHNER, M.W. (1990). Identification of cell cycle-regulated phosphorylation sites on nuclear lamin C. Cell 61: 561-577.

WILLADSEN, S.M. (1986). Nuclear transplantation in sheep embryos. Nature 320 63-65.

WILMUT, I., SCHNIEKE, A.E., MCWHIR, J., KIND, A.J. and CAMPBELL, K.H. (1997). Viable offspring derived from fetal and adult mammalian cells. Nature 385: 810-813.

WOLF, D.P., MENG, L., OUHIBI, N. and ZELINSKI-WOOTEN, M. (1999). Nuclear transfer in the rhesus monkey: practical and basic implications. Biol Reprod 60: 199-204.

WOLF, D.P., MITALIPOV, S. and NORGREN, R.B., JR. (2001). Nuclear transfer technology in mammalian cloning. Arch Med Res 32: 609-613.

WU, Y., ZHANG, Y., MISHRA, A., TARDIF, S.D. and HORNSBY, P.J. (2010). 
Generation of induced pluripotent stem cells from newborn marmoset skin fibroblasts. Stem Cell Res 4: 180-188.

YOSHIDA, M., KIJIMA, M., AKITA, M. and BEPPU, T. (1990). Potent and specific inhibition of mammalian histone deacetylase both in vivo and in vitro by trichostatin A. J Biol Chem 265: 17174-17179.

YU, J., VODYANIK, M.A., SMUGA-OTTO, K., ANTOSIEWICZ-BOURGET, J., FRANE, J.L., TIAN, S., NIE, J., JONSDOTTIR, G.A., RUOTTI, V., STEWART, R. et al. (2007). Induced pluripotent stem cell lines derived from human somatic cells. Science 318: 1917-1920.

ZELINSKI-WOOTEN, M.B., HUTCHISON, J.S., HESS, D.L., WOLF, D.P. and STOUFFER, R.L. (1995). Follicle stimulating hormone alone supports follicle growth and oocyte development in gonadotrophin-releasing hormone antagonist-treated monkeys. Hum Reprod 10: 1658-1666.

ZHANG, L., WESTON, A.M., DENNISTON, R.S., GOODEAUX, L.L., GODKE, R.A and WOLF, D.P. (1994). Developmental potential of rhesus monkey embryos produced by in vitro fertilization. Biol Reprod 51: 433-440.

ZHENG, P. (2007). Effects of in vitro maturation of monkey oocytes on their developmental capacity. Anim Reprod Sci 98: 56-71.

ZHOU, Q., YANG, S.H., DING, C.H., HE, X.C., XIE, Y.H., HILDEBRANDT, T.B. MITALIPOV, S.M., TANG, X.H., WOLF, D.P. and JI, W.Z. (2006). A comparative approach to somatic cell nuclear transfer in the rhesus monkey. Hum Reprod 21 : 2564-2571.

\section{Further Related Reading, published previously in the Int. J. Dev. Biol.}

See our recent Special Issue Developmental Hematopoiesis

edited by Charles Durand, Tierry Jaffredo and Alexander Medvinsky at:

http://www.ijdb.ehu.es/web/contents.php?vol=54\&issue=6-7

The dynamics of calcium oscillations that activate mammalian eggs

Karl Swann and Yuansong Yu

Int. J. Dev. Biol. (2008) 52: 585-594

Epigenetic reprogramming of the genome-from the germ line to the embryo and back again K L Arney, S Erhardt, R A Drewell and M A Surani

Int. J. Dev. Biol. (2001) 45: 533-540

\section{Mammalian oocyte activation: lessons from the sperm and implications for nuclear transfer}

R Alberio, $V$ Zakhartchenko, J Motlik and E Wolf

Int. J. Dev. Biol. (2001) 45: 797-809

Nuclear remodelling and early development in cryopreserved, porcine primordial germ cells following nuclear transfer into in vitromatured oocytes

L Liu, R M Moor, S Laurie and E Notarianni

Int. J. Dev. Biol. (1995) 39: 639-644

Changes in embryonic 8-cell nuclei transferred by means of cell fusion to mouse eggs

R Czolowska, D Szöllösi and M S Szöllösi

Int. J. Dev. Biol. (1992) 36: 543-553

5 yr ISI Impact Factor $(2009)=3.253$

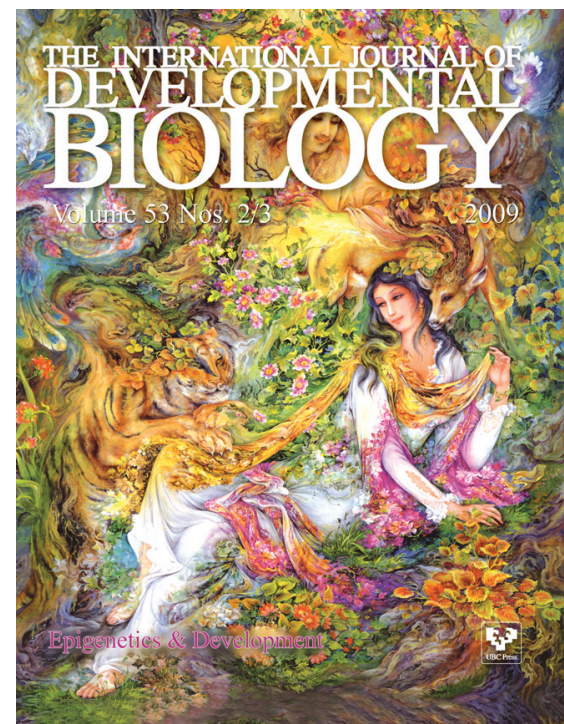

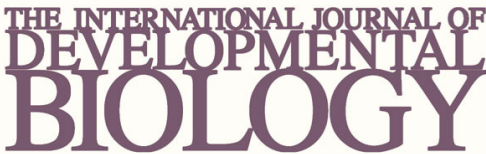

Volume 54 Nos. $6 / 7$
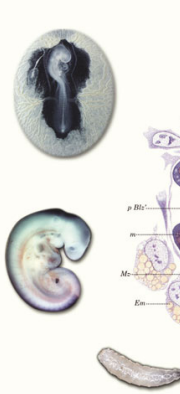

Developmental Hematopoiesis
Special Issue

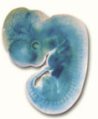

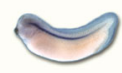
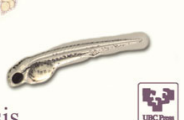

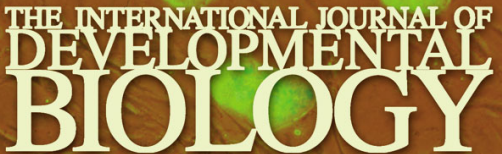

Volume 54 Nos. $11 / 12$

Special Issue

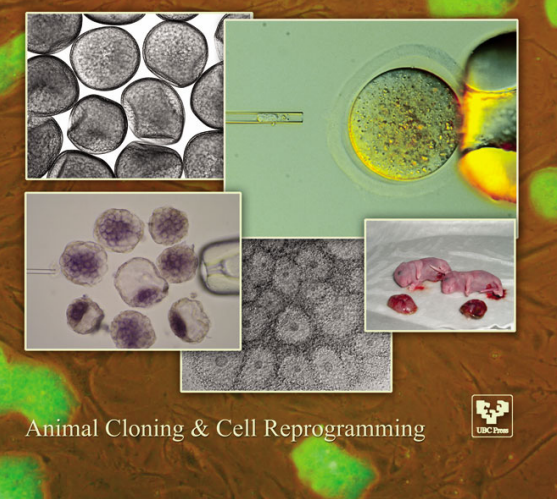

